\title{
Valérie Marin La Meslée, Balzac, «le grand parc de mes idées»
}

\section{Marco Stupazzoni}

\section{(2) OpenEdition}

\section{Journals}

\section{Edizione digitale}

URL: http://journals.openedition.org/studifrancesi/6021

DOI: 10.4000/studifrancesi.6021

ISSN: 2421-5856

\section{Editore}

Rosenberg \& Sellier

\section{Edizione cartacea}

Data di pubblicazione: 1 mai 2011

Paginazione: 189

ISSN: 0039-2944

\section{Notizia bibliografica digitale}

Marco Stupazzoni, «Valérie Marin La Meslée, Balzac, «le grand parc de mes idées»», Studi Francesi

[Online], 163 (LV | I) | 2011, online dal 30 novembre 2015, consultato il 13 janvier 2021. URL: http:// journals.openedition.org/studifrancesi/6021 ; DOI: https://doi.org/10.4000/studifrancesi.6021

Questo documento è stato generato automaticamente il 13 janvier 2021.

\section{(c) $(7)$}

Studi Francesi è distribuita con Licenza Creative Commons Attribuzione - Non commerciale - Non opere derivate 4.0 Internazionale. 


\title{
Valérie Marin La Meslée, Balzac, «le grand parc de mes idées»
}

\author{
Marco Stupazzoni
}

\section{NOTIZIA}

Valérie Marin La Meslée, Balzac, «le grand parc de mes idées», in «Le Magazine littéraire», n 497, mai 2010, pp. 100-102.

1 Si informa il lettore circa l'imminente riedizione del carnet intitolato Pensées, sujets, fragments che Balzac compose tra il 1830 e il 1847. Definito dallo stesso autore, in alcune lettere alla Hanska, come «le grand parc de mes idées», come il luogo «où j'ai mis toutes les pensées de mes ouvrages et tant de choses», questo ricchissimo quaderno contenente appunti, progetti, note, aforismi e riflessioni dello scrittore costituisce un vero e proprio laboratorio di scrittura e di progettualità romanzesca. La prima edizione di questo documento risale al 1910, pubblicato, a cura di Jacques Crepet, dall'editore A. Blaizot.

2 Segnaliamo, a p. 102, una breve nota sulla recente esposizione intitolata Mon cher George, un evento di grande interesse riguardante i rapporti tra Balzac e Sand proposta al Musée Balzac fino al 20 giugno 2010. 